In 1931, Hall was appointed research fellow of the Textile Department, Ontario Research Foundation, Toronto, where he remained for three years. There he carried on a series of investigations relating to the quality and specifications of textile materials as used in the motor car industry. This work led him into a number of separate lines of research of a fundamental character. Thus, in regard to the colour of fabrics, he devised an instrument by which it was possible to determine the fugitivity of dyestuffs under controlled conditions of temperature and moisture but under intense illumination, which greatly accelerated the fading. He was appointed to draw up standards of fastness acceptable to the two branches of industry concerned.

Other aspects of Hall's work were concerned with standards of length measurement in relation to the atmospheric humidity and hence the moisture content of textile materials. In addition to such problems as these, which were undertaken on account of their immediate importance to industry, he found time to pursue inquiries of a more academic character, particularly an investigation of the absorptive behaviour of the wool fibre in relation to the degree of swelling.

Early in 1934, Hall accepted an offer of the position of research chemist with Messrs. C. W. Martin and Sons, Ltd., Bermondsey, London, S.E.1, in connexion with their processes in dressing and dyeing fur skins.

During the past three years, Dr. Hall carried out fundamental research on the behaviour, under different conditions, of the individual fibres constituting the fur and pelt of skins. For these investigations he worked out a special technique in microscopy which led to some extremely novel and interesting results. Other problems investigated by him included 'singeing' of hairs, bleaching of ermine, and unhairing of fur seals. His abilities as a physicist proved of great value in work connected with the conditioning and drying of skins.

Hall represented the best type of scientific worker, logical, clear-thinking and of wide experience; by reason of these qualities his views commanded respect and attention. His loss will be felt not only by scientific workers who had come in touch with him but also by his colleagues and friends, who were attracted by his cheerful disposition and sound judgment. He leaves a widow and one child.

\section{Prof. J. S. Štěrba-Böhm}

By the death of Prof J. S. Sterrba-Böhm, professor of inorganic and pharmaceutical chemistry in the Charles University of Prague, on January 1 at the age of sixty-three years, Czechoslavakia has lost a distinguished investigator of international reputation. After graduating in pharmacy, Sterrba-Böhm left Prague and travelled through Austria to Serbia, and to Italy, France and Germany. In Paris he was fortunate enough to attract the attention of both Becquerel and Moissan, with whom he carried out some original work.
On returning to Prague, Šťrba-Böhm assisted Brauner in some of his investigations on the rare earths, and this work he continued after the latter's retirement. Meanwhile, an opportunity arose in 1913 and Størba-Böhm was appointed assistant professor. After the Great War, in 1919, a chair for pharmaceutical and inorganic chemistry was established for him. $\mathrm{He}$ had considerable routine work in connexion with pharmaceutical matters and in 1928-29 was dean of the Faculty of Science, but nevertheless was able to continue his researches and published much original work, mostly in Czech and French journals, on the lesser-known compounds of cerium, scandium and germanium. It was characteristic of him that he took the utmost pains to use the purest materials, a precaution which at first gave his collaborators the impression that progress was unduly slow; but it was one that is most essential in researches on the rare earths. Some years ago he prepared a long list of double oxalates of cerium with meticulous care to ensure the greatest possible purity of the salts obtained. More recently he prepared a number of scandium compounds, in particular the formate and its double compounds. Indeed, he contributed much to the chemistry of this rare metal. With a supply of argyrodite he isolated a whole series of pure germanium salts, bringing up to date the early work of Winkler on this element.

Prof. Stěrba-Böhm was of a retiring disposition but was always willing to put his knowledge at the disposal of his students and colleagues. Like many of his countrymen, he had a command of many languages and was an impressive lecturer. He was honorary foreign member of scientific societies in France, Poland, Jugoslavia and Bulgaria. G. D.

\section{Mr. T. Nelson Dale}

T. Necson DaLe, a retired member of the United States Geological Survey, died at his home in Pittsfield, Massachusetts, on November 16, nine days short of his ninety-second year.

Courses in mathematics and mineralogy at the University of Cambridge, petrography under Prof. J. Wolf at Harvard University, field trips under the leadership of Dr. Carl Zittel of the University of Munich to Norway, Sweden, France, Germany and Switzerland, and a stratigraphic and palæontological research problem in the Val de Ledro in the Tyrolese Alps, comprised the systematic part of Mr. Dale's early training. The accuracy of this first geological research, praised by Dr. Zittel and by Dr. A. Bittner of the Austrian Geological Survey, characterized all his later structural and petrographic papers written while he was associated with the United States Geological Survey, from 1880 until 1920. This work was mainly concerned with the Taconic and Green Mountain structural problems, which involved some twelve thousand miles of walking and as much of driving in the most rugged section of western New England. The mapping and the structural sections have 